\title{
Realigning Competition Advocacy Priorities in the Context of Economic Adjustment Programmes: The Greek Case
}

\author{
Dimitris Loukas
}

\section{Introduction}

This contribution aims to describe the realigned advocacy role of the Hellenic Competition Commission (thereinafter: HCC) and, in particular, its continued efforts to considerably diversify and expand advocacy and outreach activities in recent years, in order to promote structural reforms, ${ }^{1}$ pledged in the context of Greece's Stability Support Programme (thereinafter: Adjustment Programme). ${ }^{2}$ On this occasion, the contribution also aims to provide a high-level overview of Greece's reforms in the area of product and services markets, and the perceived progress achieved since the inception of the economic crisis (2009), to the extent that the HCC played a direct or indirect role with respect to it.

The HCC's increased focus on advocacy was essentially prompted by specific conditions included in Greece's Adjustment Programme (see Sect. 3). Indeed, the

The views expressed in this contribution are personal and do not necessarily represent the views and/or official position of the Hellenic Competition Commission.

${ }^{1}$ In the context of the financial and economic crisis, several EU Member States have undertaken a similar reform effort, aimed at unleashing the growth potential of their economies. Many of these reforms have been implemented under the so-called Memoranda of Understanding, in the context of Economic Adjustment Programmes, in countries such as Portugal, Greece and Cyprus, but reforms are also being promoted and monitored in countries such as Italy and Spain.

${ }^{2}$ Greece has been receiving financial support from Euro area countries and the International Monetary Fund (IMF) to cope with its financial difficulties and economic challenges, since May 2010 (after effectively losing access to the sovereign debt markets). In August 2015, a third assistance programme was launched under the European Stability Mechanism (ESM) framework. Greece's stability support programme aims to support the Greek government's efforts to: (a) address economic imbalances, (b) tackle ensuing social challenges, and (c) pave the way for sustainable economic growth and job creation.

D. Loukas

Hellenic Competition Commission, Athens, Greece

(C) The Author(s) 2018

B. Begović, D. V. Popović (eds.), Competition Authorities in South Eastern Europe,

Contributions to Economics, https://doi.org/10.1007/978-3-319-76644-7_6 
2009 financial crisis exposed the structural rigidities and inefficiencies of the Greek economy. Greece's Adjustment Programme thus entailed structural components aimed at reforming and further liberalising the product and services markets. ${ }^{3}$ This in turn triggered the most intense and sustained reform pursued by the Greek authorities in this field-a reform in which the HCC, as an independent authority, ${ }^{4}$ has played a crucial role. However, aside from the pertinent conditionalities of the Adjustment Programme, the HCC also has taken additional advocacy initiatives, thereby complementing both the reforms detailed in that Programme and its own enforcement action.

A variety of instruments have been used by the Authority for the purposes of diversifying and expanding its advocacy role, including: (a) formal opinionsrecommendations for legislative change, addressed to the government (upon request by the competent line ministries or at its own initiative); (b) targeted screening and regulatory impact assessment initiatives in cooperation with the OECD; and (c) publication of compliance and awareness guides. Each of these activities is described below (see Sects. 4-7).

\section{State-of-Play Before the Adjustment Programme}

International reports have consistently painted a grim picture of the progress made by Greece prior to 2010 in promoting structural reforms in the product and services markets, and in particular in the area of professional services. By way of example, the European Commission's 2005 Communication on Professional Services found that Greece had the highest level of regulation with regard to a number of key professional services, compared to other Member States (see Fig. 1).

\footnotetext{
${ }^{3}$ Several economic and empirical studies, e.g. Nickell (1996), Ahn (2002), Nicoletti and Scarpetta (2003), Voigt (2009), Forlani (2010), Bourlès et al. (2013), Buccirossi et al. (2013), substantiate the positive effect of competition and competition policy on macro-economic outcomes, such as productivity, growth and innovation. Fewer studies, e.g. Mitsopoulos and Pelagidis (2009), Ioannides et al. (2014), Kourandi (2014), Zonzilos (2014), Kotsi et al. (2015), (2016), have recently attempted to address the impact of business environment reforms in the Greek context, albeit most pertinent evidence can be found in regular reports of international organisations, e.g. European Commission, IMF, OECD, World Bank and Bank of Greece, on the occasion of Greece's ongoing economic adjustment programme.

${ }^{4}$ The HCC has the status of an independent administrative authority, in accordance with Greek law. In particular, the HCC enjoys both administrative independence (notably in the sense that there is no oversight or involvement of ministries or other members of the executive in its decision-making process, nor in the selection of staff for management posts within its services or with regard to other administrative decisions usually associated with internal organization and enforcement operations; its Board members are appointed through special parliamentary procedure, while the Authority reports annually to Parliament) and financial independence (in the sense that it has its own financial resources in the form of a contributory fee paid by enterprises and it is not financed through the State budget).
} 


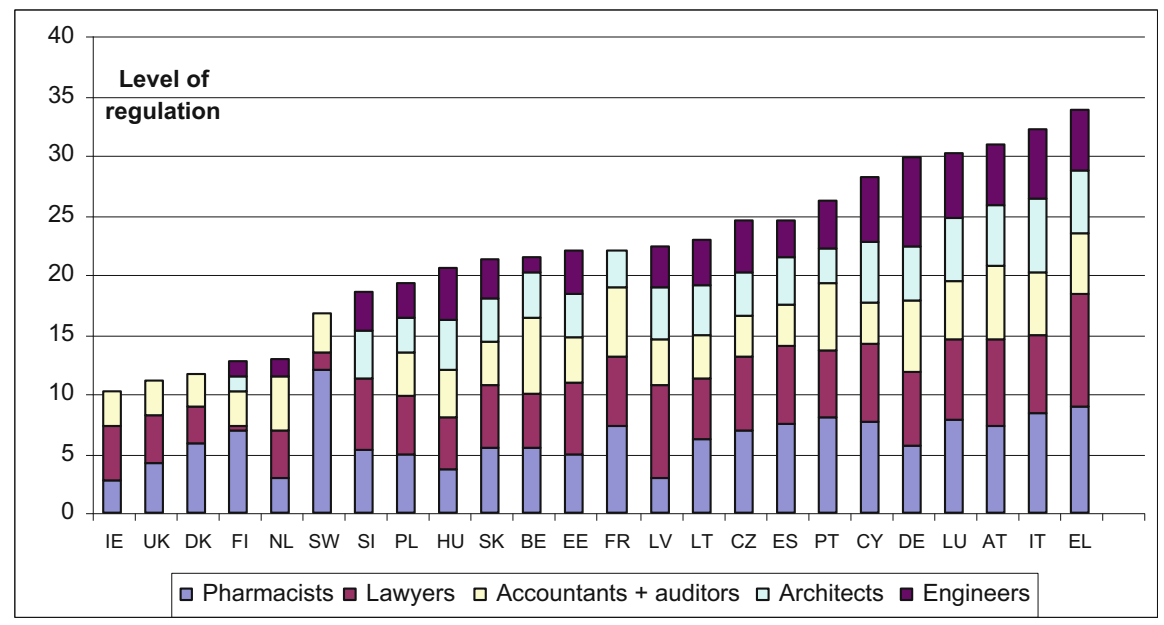

Fig. 1 Level of regulation in Member States (2005). Source: EUR-Lex database (2005)

According to the EU Commission's findings, Greece did not avail itself of the opportunity to promote structural reforms in professional services in 2004-2005, ${ }^{5}$ thereby lagging significantly behind other Member States, based on a comparison of Greece's reform activity against its level of then existing regulation in the professional services sector.

Similarly, the OECD has consistently recorded a high and intense level of regulation in product and services markets in Greece relative to most other OECD Members (see Figs. 2, 3, 4, and 5).

\section{Increased Focus on Advocacy: Realigned Strategy}

Against this backdrop, the Adjustment Programme entailed several milestones pertaining to structural reforms, which in turn prompted the HCC's enhanced focus in advocacy. From the point of view of the Authority, three main pillars

\footnotetext{
${ }^{5}$ After a series of fact-finding and comparative studies between 2001 and 2003, in the context of the Lisbon Agenda, followed by a structured dialogue with professional associations during 2003-2004, the Commission published a Report on Competition in Professional Services, in February 2004. This Report was supplemented by the Stocktaking Exercise on Regulation of Professional Services in the new EU Member States, published in November 2004. Finally, in September 2005, the Commission issued a follow-up to the 2004 Report, the Professional Services-Scope for More Reform Communication. Overall, national governments were essentially called upon to review the compatibility of their national legislations with EU law and to liberalize professional services in an attempt to promote further internal market integration. However, not all Member States corresponded accordingly.
} 


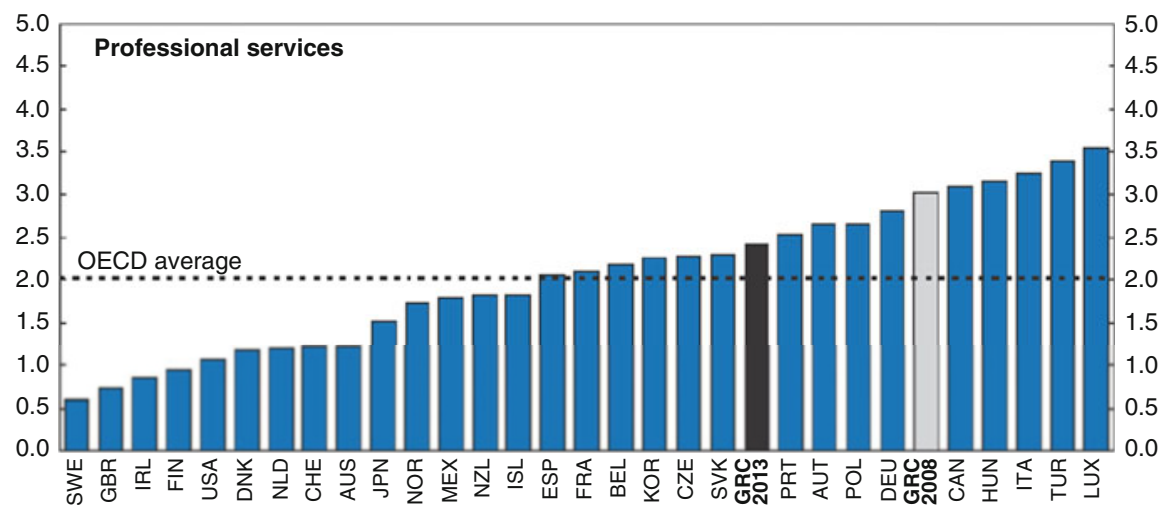

Fig. 2 Regulatory barriers in professional services. Progress made by Greece-OECD PMR (2013a). Source: OECD (2013b), Regulatory barriers in professional services: Index scale from 0 (least restrictive) to 6 (most restrictive), in OECD Economic Surveys: Greece 2013, OECD Publishing, Paris. https://doi.org/10.1787/eco_surveys-grc-2013-graph-46-en

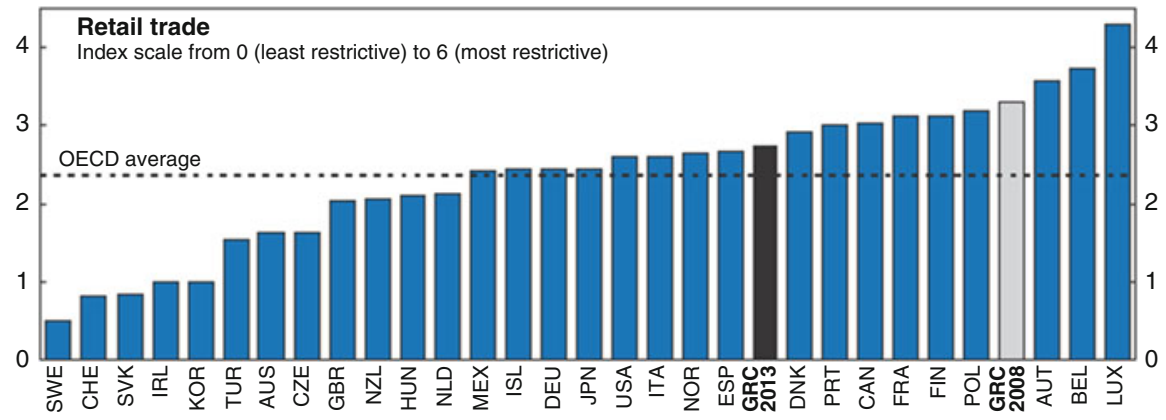

Fig. 3 Regulatory barriers in retail services. Progress made by Greece-OECD PMR (2013a). Source: OECD (2013b), OECD Economic Surveys: Greece 2013, OECD Publishing, Paris. https:// doi.org/10.1787/eco_surveys-grc-2013-en

underpinned its priorities in coping with the severe economic crisis, while also contributing to the implementation of the Adjustment Programme:

- maintaining a consistent level of competition enforcement regardless of the crisis, while adapting case allocation and focus;

- strengthening market monitoring activities; and

- considerably diversifying and expanding competition advocacy and outreach efforts, in order to promote structural reforms (pledged in the context of Greece's Economic Adjustment Programme), and increase overall competition awareness. 


\section{OECD - Product Market Regulation index}

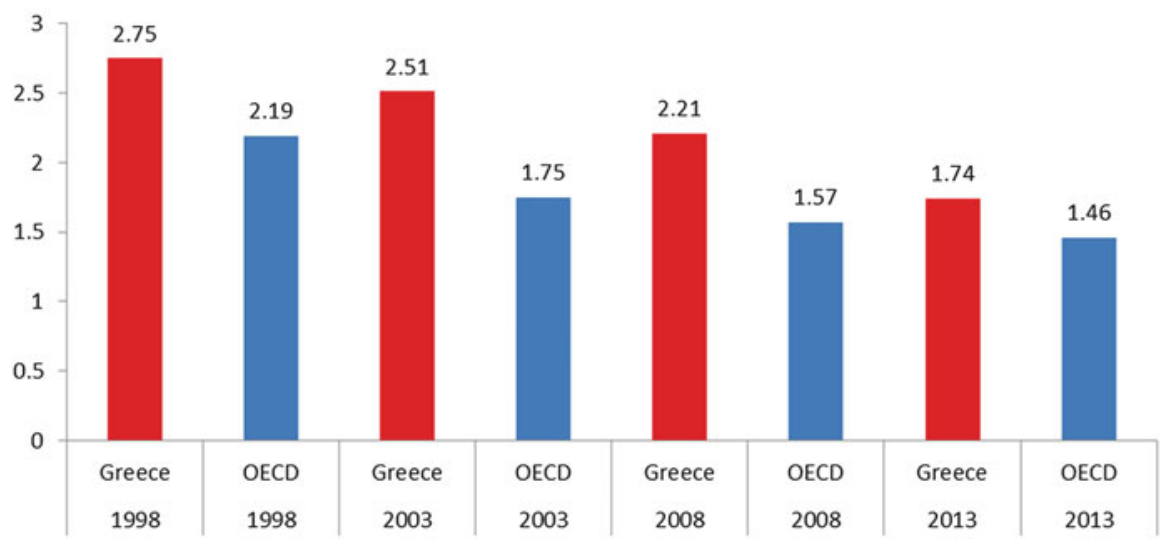

Fig. 4 Regulatory barriers in retail services. Comparison Greece v. OECD Average-OECD PMR (2013a). Source: Prepared by the author based on the OECD Indicators of Product Market Regulation database, http://www.oecd.org/eco/growth/indicatorsofproductmarketregulationhomepage. htm\#indicators

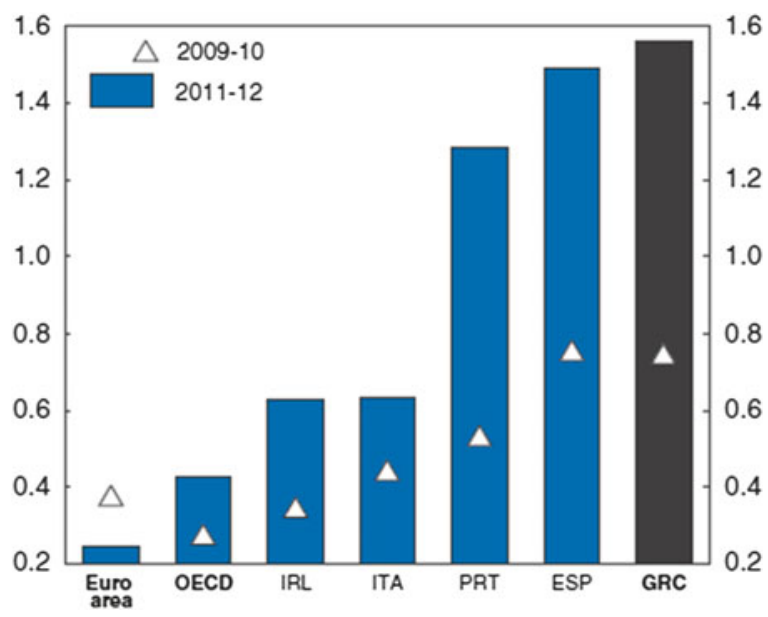

Fig. 5 Responsiveness to structural reforms recommended by the OECD. Adjusted for the difficulty of undertaking reform (2013). Source: OECD (2013b), Responsiveness to OECD structural reforms recommended in Going for Growth: Adjusted for the difficulty of undertaking reform, in OECD Economic Surveys: Greece 2013, OECD Publishing, Paris. https://doi.org/10.1787/eco_ surveys-grc-2013-graph9-en

In particular, the HCC allocated a significant part of its resources to advocacy functions, focused primarily on identifying and removing regulatory obstacles to competition and promoting a genuine competition culture, through outreach activities. During the 2011-2014 period, advocacy work accounted for up to $25 \%$ of the 
HCC's total output. ${ }^{6}$ Furthermore, it amounted to $15 \%$ of total output during 2013, thus maintaining record levels compared with the OECD average.

As mentioned, the main reason that prompted the Authority's increased focus on competition advocacy had to do with the Adjustment Programme, in response to the unprecedented economic crisis, which had exposed the structural rigidities and inefficiencies of the Greek economy. In this context, the HCC realigned its strategy, so as to increase the exercise of its advisory powers in the field of identifying and removing regulatory obstacles to competition - the objective being to complement the core enforcement work with initiatives promoting structural reforms-while further promoting competition awareness in areas exhibiting a high risk of anticompetitive conduct (as indicated by recent enforcement action and ensuing patterns in terms of likely and/or repetitive types of infringers). Two factors contributed to this strategic re-alignment:

- the revision of the Greek Competition Act (Law 3959/2011), which gave the HCC the power to issue formal opinions/recommendations for draft legislation potentially affecting competition ${ }^{7}$; and

- specific provisions in the context of Greece's Adjustment Programme, agreed between the EU-ECB-IMF and the Greek government, which gave the Authority a special role in promoting certain reforms (notably, in the area of professional services).

Since 2011, the HCC's advocacy and outreach agenda has revolved around four key themes:

- liberalization of professional services (liberal professions),

- Greece's Competition Assessment Projects-ex post competition assessment of laws and regulations (an OECD-managed project, in partnership with the HCC, which applied the OECD's Competition Assessment Toolkit ${ }^{8}$ in designated sectors of the Greek economy), and

- addressing legislative distortions mostly affecting retail and food supply chains,

\footnotetext{
${ }^{6}$ Measured by the total number of formal decisions and recommendations issued by the HCC in that time frame.

${ }^{7}$ The revision of the Greek Competition Act was a condition of the first Adjustment Programme. In particular, the commitment agreed upon by the Greek government in the context of the Adjustment Programme included the abolition of the notification system for anti-competitive agreements that would allow a full-fledged pass-on to the "legal exemption" regime (as established by EU Regulation 1/2003), the introduction of a prioritisation system regarding complaints that would enhance the HCC's competence to reject complaints, the strengthening of the HCC's members independence and the establishment of a more reasonable time-frame for the resolution of cases.

${ }^{8}$ The OECD's Competition Assessment Toolkit helps governments to eliminate barriers to competition by providing a method for identifying unnecessary restraints on market activities and developing alternative, less restrictive measures that still achieve government policy objectives. The full text of the OECD's Competition Assessment Toolkit, including principles and guidelines for applying the methodology set out therein, can be found at: http://www.oecd.org/daf/competi tion/assessment-toolkit.htm. The Toolkit was first published in 2007 and then updated in 2010 and 2015. The updated version provides additional examples of the benefits of competition and is
} 
- the publication of competition compliance and awareness guides, primarily addressing trade associations, as well as procurement/contract awarding public authorities.

Each of these advocacy initiatives is further explained below.

\section{Liberalization of Professional Services}

In the context of Greece's Adjustment Programme, the HCC (as an independent authority) was called upon to issue formal opinions/recommendations aimed at liberalising several professions. This was an exercise that essentially consisted of an extensive review of existing laws and regulations from the point of view of competition, focusing on the entry and exercise of a number of regulated professions.

This prompted the most far-reaching intervention by the HCC in the area of liberal professions (and the most far-reaching intervention ever in terms of regulatory obstacles to competition). During 2011-2012 alone, the HCC's task force on liberal professions reviewed laws and regulations affecting more than 55 regulated professions (ultimately issuing 17 formal opinions). The following year (2013), the $\mathrm{HCC}$ issued three new formal opinions aimed at identifying and removing regulatory obstacles pertaining to the access and exercise of a number of professional services.

Overall, the professional services reviewed by the HCC in this context fell within two broad categories. The first category included some key regulated professions, such as lawyers, accountants, and engineers, which were addressed specifically by Law 3919/2011. In particular, this legislation, which was a significant component of Greece's action plan on structural reforms: (1) provided for the across-the-board abolition of a number of restrictions affecting all liberal professions, including fixing of fees, ${ }^{9}$ entry requirements, and reserved rights/activities ${ }^{10}$ (e.g. quantitative and/or qualitative admission requirements to a profession, fixed number of professionals

further supplemented by a companion volume with detailed technical guidance on key issues to be considered when performing competition assessment.

${ }^{9}$ This restriction, notably in the form of fixed or minimum fees/prices/charges for professional services provided, is perceived to have the most detrimental effects on competition. Recommended prices may also potentially have a negative effect on competition, as it may facilitate the coordination of prices between service providers and/or mislead consumers about reasonable price levels.

${ }^{10}$ Excessive licensing regulation is also perceived as reducing the supply of service providers, with negative consequences for competition and quality of service. According to the EU Commission's findings, several professions are subject to qualitative entry restrictions in most Member States. Furthermore, in many cases, entry restrictions are coupled with reserved rights to provide certain services (e.g. in some Member States the pharmacist and notary professions are even subject to quantitative entry restrictions based on demographic criteria). Unjustified entry restrictions of that sort, combined with reserved rights, may restrict new entries and increase of output to the detriment of competition and economic efficiency. 
allowed to exercise a profession, territorial restrictions in the exercise of a profession $^{11}$ ), restrictions on advertising, ${ }^{12}$ etc.; (2) replaced the previous administrative license system (where applicable) with a simple notification and ex-post review system; and (3) included specific provisions for the liberalization of certain key regulated professions, such as lawyers, notaries, chartered accountants, and engineers. For the latter selected professional activities, the HCC issued a number of recommendations, including for example:

- for lawyers: the removal of fixed minimum fees, advertising restrictions, and also territorial restrictions on where lawyers can practice in Greece;

- for notaries: the relaxing of rules on fixed fees and the maximum number of notaries allowed to operate per prefecture;

- for architects/engineers: the removal of fixed minimum fees; and

- for chartered accountants: the removal of fixed minimum fees.

The second category included all other liberal professions, where a horizontal approach was opted for by Law 3919/2011. As indicated above, for all other professional activities, the legislation just provided, in a general manner, for the abolition of certain regulatory restrictions (e.g. fixing of fees, quantitative entry requirements and territorial restrictions, etc.) and for the abolition of the previous administrative license system for the entry into and exercising of each profession.

However, it also provided the opportunity to obtain exemption from full liberalization by profession, on the basis of overriding public policy considerations and being subject to the principle of proportionality. In this context, the government entrusted the $\mathrm{HCC}$ with the task of reviewing all such exemption requests pertaining to Law 3919/2011, i.e. requests to maintain and/or re-instate prior authorization requirements and other restrictions regarding the exercising and access to those liberal professions where the across-the-board liberalization approach had been applied. In this regard, the HCC applied the key methodology of the OECD Competition Toolkit and/or similar competition impact assessment techniques, notably by assessing and weighing public policy considerations in light of the principle of proportionality. By way of example, the HCC reviewed exemption requests pertaining to the following professions: chartered (sworn-in) appraisers/ valuers; actuaries; accountants; tax consultants; geotechnicians (including the production and marketing of propagating material and fertilizers); licensed providers of services relating to public security and public safety; tourist guides; licensed providers of educational services; licensed providers of health-related services; and licensed sellers of tobacco products.

\footnotetext{
${ }^{11}$ Usually, requirements that licensed professionals exercise the profession within a particular geographic area of Greece or restrictions on their ability to open and/or operate from a secondary/subsidiary establishment (outside the primary geographic area of their activities).

${ }^{12}$ Advertising may similarly facilitate competition by informing consumers about different products and allowing them to make better-informed purchasing decisions. It is also widely recognized that advertising, and in particular comparative advertising, can be a crucial competitive tool for new firms that are entering the market and for existing firms that want to launch new products.
} 
The intensity of the HCC's review varied according to the conditions prevailing in each profession. In certain cases, the Authority's recommendations were tailoredmade as to correspond to the specific exemption request made, while in other cases the HCC opted for issuing wide-ranging recommendations (essentially comprising an overhaul of the way a certain profession is organised and performed).

The opinion concerning chartered (sworn in) appraisers/valuers (HCC Opinion No. 16/VI/2012) is an example of the latter approach. In their request for exemption, chartered appraisers asked to maintain: (i) the limited access to the profession (numerus clausus), (ii) the exclusive rights to provide certain valuation services, (iii) the prohibition in the exercise of the profession by legal entities or other EU nationals, and (iv) their fixed remuneration. In doing so, they claimed overriding public policy considerations, such as the protection of consumers and the effectiveness of the tax collection system. However, in its opinion/recommendations addressed to the government, the HCC found that the stated public considerations were not substantiated and, in any event, did not comply with the principle of proportionality. The HCC, therefore, recommended that all such restrictions should be lifted. Furthermore, after reviewing the conditions of entry into, and exercise of, this profession, the HCC further proposed, inter alia, that the membership of the appraisers' organization be substantially broadened based on transparent and objective criteria, either through the admission of all natural and legal entities having equivalent vocational qualifications or, alternatively, by accrediting additional (and competing) professional associations. The HCC also recommended that a registry of certified appraisers be created (by specialty).

Following the conclusion of the exemption review exercise, the Greek government proceeded with the adoption of the secondary legislation necessary to ensure the proper implementation of the reform. To that effect, the Ministry of Finance, in cooperation with the respective competent line ministries by profession, issued a large number of decrees, administrative orders, and mostly circulars addressed to the administration, thereby clarifying the applicable (new) rules by profession, as well the conditions for entry and exercise of each profession.

Overall, according to OECD estimates included in Greece's Economic Survey (Nov. 2013), around $75 \%$ of nearly 350 regulated professions were opened to competition by the beginning of 2013, in line with the Hellenic Competition Commission recommendations.

Moving forward, the HCC participated in several follow-on reviews coordinated by the Ministry of Economy (2014-2016), aimed at reviewing the qualifications and other requirements for entry into a number of regulated professions, with a view to lift unnecessary restrictions and overall simplifying access.

By way of example, the HCC issued Opinion No. 34/2014, following a formal request from the Greek Government, on a draft legislation amending the current national legal framework on professional rights of engineers. To this end, the HCC underlined the need for a general revision of the legal framework for the engineering profession and its consolidation into one piece of legislation, as well as the need to remove, uniformly and systematically, the existing contradictions and ambiguities for all engineering projects, public or private. The HCC proposed that the new legal 
framework: (a) describe the shared and, where necessary and proportionate in light of overriding public interest, the exclusive professional activities of engineers with different specialties, and (b) identify objective criteria for access to and exercise of those professions, based on the engineer's expertise, aptitudes and experience, without reference solely to specific academic titles. The HCC also proposed integrating the current separate registries related to the construction industry based on objective criteria. Finally, the new legal framework could be supplemented by rules of professional conduct and responsibility, which would enable the development and adoption of self-regulatory rules. As immediate measures, the HCC recommended that the government amend the current legislation on civil engineers, architects and topographers so that access to specific professions is determined by objective criteria of expertise and experience, and not merely by reference to academic titles granted by specific institutions. Additionally, the HCC suggested amending specific provisions of the draft laws to ensure equivalence of professional rights among graduates of universities, whether national or foreign, that award engineer degrees corresponding to the abovementioned professions. Following this Opinion, the HCC acted as chair of a legislative committee assigned the task of drawing up Presidential Decrees regarding the criteria for access to, and exercise of, the engineering profession.

\section{Greece's OECD Competition Assessment Project}

\subsection{First Competition Assessment Project}

The year 2013 saw the successful completion of the most intense advocacy project in recent years, Greece's OECD Competition Assessment Project. During the course of 10 months, a core project team consisting of competition experts from both the OECD and the HCC carried out an assessment of the costs and benefits of regulations potentially restricting competition in four designated sectors of the Greek economy, namely ${ }^{13}$ : retail trade, food processing, building materials, and tourism.

The aim of the project was to evaluate existing regulations and propose alternative (less restrictive) regulations, in order to increase competition and bring about longer-term gains to productivity and economic growth. Using the methodology set out in the OECD's Competition Toolkit, the team of experts reviewed more than 1000 pieces of legislation, ultimately identifying 555 problematic regulations and making more than 320 recommendations for legal provisions that should be amended or repealed. By way of example, recommendations included:

\footnotetext{
${ }^{13}$ These sectors represented $21 \%$ of Greece's GDP output, and had a combined turnover of 44.26 billion euros (2011 data). They also represented 1,103,500 jobs, i.e. $24.8 \%$ of the total employment in Greece. Lifting the restrictions to competition in these sectors was therefore likely to have significant positive economic impact, both in the short term and in the long term.
} 
- abolishing requirements to seek price approval or price notifications to the authorities or industry associations;

- removing all third-party levies and fees (including the tax on advertising and the levies on flour and cement);

- fully liberalising Sunday trading;

- lifting the 5-day restriction on the shelf life of fresh milk (and replace with less restrictive labelling arrangements);

- liberalising prices of over-the-counter medicines (OTCs) and dietary supplements, as well as distribution channels;

- relaxing regulations on shop promotions and discounts;

- relaxing regulations on cruises and moorings, while allowing marina operators to compete with nearby commercial or fishing ports on prices;

- abolishing all barriers to entry that have been identified (e.g. licensing requirements in the asphalt sector; minimum requirements for storage, or minimum capital requirements in the building materials sector; numerous barriers to investment in tourism activities, such as geographical restrictions or minimum quality requirements; limits on tourist coach activities; restrictions on offices of travel agents; limits to the trade of blended olive oils); and

- removing horizontal regulations that hamper or thwart the proper functioning of markets.

According to the findings from this project, if the recommendations detailed in the report are implemented, considerable benefits are likely to accrue. The project sought to identify the sources of those benefits and, where possible, provide quantitative estimates, either on the basis of certain experiences of deregulation in other countries, or by relating conservative estimates of efficiency gains to the overall size of the business activity affected. Overall, by referencing 66 recommendations out of 329 , the project estimated a positive effect for the Greek economy of around 5.2 billion euros, which represents the total of the estimated resulting positive effects on consumer surplus, increased expenditure and higher turnover in the sectors analysed, as a result of the removal of regulatory barriers to competition. The cumulative longterm impact of the lifting of all the restrictions was considered likely to be greater.

Following the publication of the report, the Greek government announced its intention to adopt approximately $80 \%$ of the recommendations made, through legislation. The IMF estimated that 237 of the 329 recommendations were fully implemented by June 2014 (IMF Country Report No.14/151). Most of these implemented recommendations were enacted into law by Act No. L. 4254/2014. However, a number of politically sensitive recommendations (e.g. on liberalising Sunday trading, liberalising prices and distribution channels for OTCs and dietary supplements, and extending the shelf life of fresh milk) were adopted either in a partial or in a pilot manner, with some ultimately abandoned, following strong opposition by the professional/trade associations most affected by them. 


\subsection{Second Competition Assessment Project}

The second phase of the project was successfully completed in December 2014, following a 5-month in-depth review of legislation, aimed at identifying potential regulatory obstacles to competition in four additional sectors of the economy:

- manufacture of coke and refined petroleum products;

- manufacture of textiles, wearing apparel, leather and related products;

- manufacture of beverages; and

- manufacture of machinery and equipment.

The team of experts reviewed 482 pieces of legislation, identified 154 potential restrictions, and made 88 recommendations for change. The vast majority of these recommendations were subsequently enacted into law (with less recorded opposition levelled against them by professional and trade associations alike).

\subsection{Third Competition Assessment Project}

Following the successful implementation of the first and the second OECD Competition Assessment Projects, a third phase of the Competition Assessment Project was initiated in 2015 and concluded in 2016. Again, the core project team, consisting of competition experts from both the OECD and the HCC, undertook an assessment of regulations potentially restricting competition in the following designated sectors of the Greek economy:

- e-commerce,

- construction,

- media,

- wholesale trade, and

- select subsectors of manufacturing, such as chemicals and pharmaceuticals.

Using the methodology provided in the Competition Assessment Toolkit, the team examined 1288 sector-relevant pieces of legislation, identified 577 possible restrictions to competition, and made 356 recommendations to correct them by less restrictive policies. Similarly, the vast majority of these recommendations were subsequently enacted into law (with less recorded opposition levelled against them by both professional and trade associations, particularly in view of their less politically sensitive nature).

Overall, the HCC's partnership with the OECD on these competition assessment projects has been a testament to the Authority's capabilities and commitment to further strengthening its advocacy role. 


\section{Other Initiatives Regarding Regulatory Distortions Mostly Affecting Retail and the Food Supply Chain}

In addition to the abovementioned exercising of its consultative powers under the new Competition Act, and in the context of Greece's Economic Adjustment Programme, the $\mathrm{HCC}$ has pursued additional initiatives to promote a genuine competition culture. These advocacy initiatives have mostly targeted regulatory distortions affecting retail and the functioning of the food supply chain, but they also have had a broader educational function.

For example, the HCC issued recommendations focusing on:

- the reform of the so-called Product and Market Regulation Code, ${ }^{14}$ in particular by (a) abolishing all delegated powers concerning minimum and/or fixed prices, export bans and/or export restrictions, as well as transportation fees, and (b) retaining certain delegated powers to regulate the conditions for the sale and marketing of certain products only to the extent they comply with EU regulations;

- the abolition of the regulation requiring that all types of infant milk (formulas) for infants under the age of 6 months be sold solely through pharmacies;

- the abolition of the obligation imposed on companies to regularly report their wholesale price lists to the competent line ministry; and

- the removal of regulatory obstacles impeding effective competition in the fuel and the cement sectors.

Some of these recommendations were ultimately enacted into law by the Greek government, while others were adopted partially (recommendations in the fuel and cement sectors), or not effectively implemented (lifting of the restriction to sell baby formulas only through pharmacies). ${ }^{15}$

More recently, the HCC participated in two reviews, undertaken by the Ministry of Development and Competiveness, regarding:

- a market study focusing on barriers to entry to the wholesale sector (completed in December 2014),

- a market study focusing on barriers to entry in e-commerce (completed in December 2014), as well as

- preparation of a Code of Conduct for rebates, offers, promotional actions and stock management (the committee set up for this purpose submitted its final proposal in September 2014, and a Ministerial Decision by the Minister of Development and Competitiveness was issued in November 2014).

\footnotetext{
${ }^{14}$ This Code is essentially a consolidated version of all applicable implementing legislation pertaining to the way products are marketed and sold through various distribution channels in Greece (partly transposing EU legislation in that respect).

${ }^{15}$ The Greek Pharmacists Association successfully challenged the Ministerial Decision implementing this liberalization measure before Greece's Supreme Administrative Court. However, subsequently, and following pressure by the creditors in the context of the Adjustment Project, the measure was re-enacted as a law.
} 


\section{Overall Progress: Indices}

Due to the ongoing recession and the transitional phase of the Greek economy, it is still difficult to quantify the benefits to economic growth brought about by such liberalization efforts and/or measure them in terms of e.g. new professionals entering a specific profession or economic activity in specific sectors, expanding the whole. Nonetheless, several comparative assessment reports, notably those carried out regularly by the OECD, clearly capture Greece's advancement in removing regulatory barriers in professional services to the benefit of competition. ${ }^{16}$ Figures 2, 3, and 4 are telling in that respect.

The Greek Centre of Planning and Economic Research (KEPE) reported similar findings in two relatively recent impact assessment reports pertaining to the liberalization of professional services in Greece. In particular, Kotsi et al. (2016) recorded significant progress in terms of lowering the scope and intensity of regulation mostly related to the conditions for entry to a number of professions in Greece and, to a lesser extent, the conditions for exercising those professions. Similarly, the report concludes that it is difficult to quantify-given the transitional status of the Greek economy-the concrete benefits brought about by these liberalization efforts or to determine to what extent the observed decrease in prices of certain professional services are attributable to the implementation of the structural reforms under consideration.

Similarly, considerable progress is recorded by the OECD (2013a, b, c) in terms of promoting structural reforms in the retail sector (relative to other OECD member countries), as well as with respect to the level and intensity of product market regulation as a whole:

The perceived responsiveness of the Greek administration to structural reforms, as adjusted for the difficulty in undertaking those reforms (e.g. in view of the continuous economic crisis, their ensuing impact on and/or resistance of vested interests), is also deemed more significant relative to other OECD Members for that same period (see Fig. 5).

As an aside, the Word Bank Doing Business Survey recorded significant progress made by Greece in terms of easing conditions of entry into business during the 2011-2014 period (by the overall cutting red tape, relaxing regulations and reducing costs), notably as compared to Italy, Portugal and Spain, which is consistent with the above OECD findings.

\footnotetext{
${ }^{16}$ According to the OECD's Economic Survey of Greece (Nov. 2013), significant progress has been achieved overall in promoting market reforms, since the inception of the crisis (2009-2010), albeit from a low starting point. The OECD recommended that product and services reforms be continued unabated, as such regulations were still (as of early 2013) among the most restrictive in the OECD.
} 


\section{Competition Compliance and Awareness Guides and Other Outreach Activities}

During the last 5 years (2011-2016), the HCC also issued a number of compliance and awareness guides promoting competition. The following campaigns are noteworthy.

\subsection{Trade Associations}

The HCC launched an initiative to publish a new competition compliance guide, specifically addressing trade associations. This initiative was complemented by speeches and workshops, undertaken by the Authority in cooperation with interested professional associations, the aim being to promote awareness of competition law and of the overall benefits of effective competition. The HCC's advocacy focus on trade associations follows a relatively high number of infringement decisions issued in recent years related to collusive practices by trade associations and other professional bodies. This appears to be a Greek particularity as compared to most other EU Member States. However, it comes as a direct result of the disproportionate number of self-employed professionals and of the intra-profession protectionist culture still widespread in the services markets. The Authority's outreach efforts in this regard aim to promote a genuine competition culture and encourage self-regulation that respects competition rules.

\subsection{Public Procurement and Bid-Rigging}

A new guide specifically addressing public procurement/contract awarding entities was published in 2015, particularly focusing on practical examples and methods to detect and/or avert bid-rigging. The Guide for Public Procurement Authorities: Detection and Prevention of Collusive Practices in Procurement Tenders specifically aimed at enhancing the awareness of public officials with regard to bid-rigging practices. It was followed by two competition training sessions for public procurement officials on bid-rigging detection and prevention (partly in cooperation with the OECD). As indicated by recent HCC enforcement activities, ${ }^{17}$ this is an area that increasingly exhibits a high risk of anticompetitive conduct, thus the need for the Authority to engage in focused outreach activities.

\footnotetext{
${ }^{17}$ See e.g. HCC investigations into the construction sector, haemodialysis filters, and waste management.
} 


\subsection{Franchising}

Likewise, the HCC issued guidelines (in the form of Q\&As) with regard to the application of competition law rules in franchise agreements, in order to help franchisors and franchisees understand the types of conduct that may infringe competition law.

\subsection{Regulatory Impact Assessment: Legislative Process}

The HCC is currently cooperating closely with the General Secretariat of the Government in an attempt to promote a coherent Regulatory Impact Assessment (RIA) strategy at the central administration level. In this context, the Authority will be publishing competition-specific guidelines for the assessment of laws and regulation by the competent line ministries-competition being a significant component of the RIA.

\section{Concluding Remarks}

The scope and intensity of the Authority's advocacy agenda in recent years has involved certain risks. The first risk pertains to the over-extension of scarce human resources, often to the detriment of expeditious and effective enforcement. The second risk pertains to the possibility of non-competition policy considerations creeping in to the Authority's decision making process in the area of advocacy, given that its recommendations often entail special weight pursuant to the Adjustment Programme and, as a result, there is increased pressure to give precedence to other policy considerations (incl. Social policy, labour issues, etc.) when carrying out the assessment of laws and regulations.

However, one needs to recall that the HCC's efforts in this regard have taken place against a backdrop of the longest and steepest recession in the history of the European Union, with the Greek economy in 2013 contracting for the sixth consecutive year (a cumulative drop in real GDP of more than $20 \%$ since the inception of the crisis, coupled with record levels of unemployment). Several studies suggest that economic recovery in Greece has been partly hampered by the prevailing situation in the products and services markets, which remain among the most strictly regulated markets in the OECD area. Therefore, structural reforms, particularly in the context of professional services, are a necessary precondition for overcoming the constraints imposed by the crisis, for building competitive industries that can withstand international pressure, and, ultimately, for sustaining a new growth model that will realise the economy's productive potential. 
It is important to carefully design the timing and manner of publicly presenting the outcomes of the competition assessment review, particularly in cases where there is a trade off in terms of the cost of implementing the proposed recommendations (e.g. a funding gap created by lifting third-party levies on goods or services), so as to mitigate adverse publicity and allow for a substantive debate on the optimal way forward, while anticipating unfounded opposition by professional vested interests.

Most importantly, the HCC's recent experience in advocacy and other outreach efforts speaks plainly about the urgent need to change the legislation production process, the need to pursue efficient outcomes that more accurately reflect the general public interest, and the need to move away from often favouring the interests of certain professional groups and other vested interests. In particular, it speaks towards the need to implement a coherent Regulatory Impact Assessment strategy at the level of the central administration, so as to promote the ex ante control of draft laws and regulations, thereby pre-empting regulatory barriers to competition and safeguarding the previously implemented reforms. This is particularly important, as the conclusion of the Adjustment Programme is most likely to ease the pressure on the central administration to continue promoting structural reforms.

\section{References}

Ahn S (2002) Competition, innovation and productivity growth. OECD economics department working papers, no. 137. https://doi.org/10.1787/182144868160

Bourlès R, Cette G, Lopez J, Mairesse J, Nicoletti G (2013) Do product market regulations in upstream sectors curb productivity growth? Panel data evidence for OECD countries. Rev Econ and Stat 95(5):1750-1768. https://doi.org/10.1162/rest_a_00338

Buccirossi P, Ciari L, Duso T, Spagnolo G, Vitale C (2013) Competition policy and productivity growth: an empirical assessment. Rev Econ Stat 95(4):1324-1336. https://doi.org/10.1162/rest_ a_00304

EUR-Lex database (2005) Communication from the commission to the council, the European Parliament, the European economic and social committee and the committee of the regionsprofessional services-scope for more reform-follow-up to the report on competition in professional services, COM(2004) 83 of 9 February 2004 (SEC(2005) 1064) /* COM/2005/ 0405 final (hereinafter: 2005 communication). http://eur-lex.europa.eu/legal-content/en/TXT/? uri $=$ CELEX\%3A52005DC0405

Forlani E (2010) Competition in the services sector and the performances of manufacturing firms: does liberalization matter? CESifo working paper no. 2942. https://www.cesifo-group.de/ DocDL/cesifo1_wp2973.pdf. Accessed 8 Nov 2017

Hellenic Competition Commission (2012-2015) Annual reports 2012, 2013, 2014, 2015. https:// www.epant.gr/. Accessed 8 Nov 2017

Hellenic Competition Commission (2012-2015) Annual report on competition policy developments (submissions to the OECD). https://www.epant.gr/. Accessed 8 Nov 2017

IMF (2014, June) IMF country report no. 14/151. http://www.imf.org/external/pubs/ft/scr/2014/ cr14151.pdf. Accessed 8 Nov 2017

Ioannides S, Danchev S, Giotopoulos I, Paratsiokas N, Pavlou G, Peppas K, Stavraki S (2014) The microeconomic effects of business environment reforms. http://ketlib.lib.unipi.gr/xmlui/ bitstream/handle/ket/671/micro_effects_business_environment_reforms_en.pdf?sequence=2. Accessed 8 Nov 2017 
Kotsi A, Athanassiou E, Kanellopoulos NC, Karagiannis R, Papaioannou S, Katselidis I (2015) Liberalization of professions: extent and expected effect. Report no 71, resource document. The Centre of Planning and Economic Research (KEPE). https://www.kepe.gr/index.php/en/ research/recent-publications/reports/item/2734-vathmos_apel. Accessed 8 Nov 2017

Kotsi A, Athanassiou E, Kanellopoulos NC, Karagiannis R, Katselidis I (2016) Impact assessment of the liberalization in 20 professions. Report no 73, resource document. The Centre of Planning and Economic Research (KEPE). https://www.kepe.gr/index.php/en/research/recent-publica tions/reports/item/2830-ek_73_en. Accessed 8 Nov 2017

Kourandi F (2014) Indicators of business performance and progress reform. National and Kapodistrian University of Athens. http://ketlib.lib.unipi.gr/xmlui/bitstream/handle/ket/669/indi cators_final_report_en.pdf?sequence $=2$

Mitsopoulos M, Pelagidis T (2009) Vikings in Greece: kleptocratic interest groups in a closed, rentseeking economy. Cato J 29(3). http://citeseerx.ist.psu.edu/viewdoc/download?doi=10.1.1. $306.6716 \&$ rep $=$ rep $1 \&$ type $=$ pdf. Accessed 8 Nov 2017

Nickell SJ (1996) Competition and corporate performance. J Polit Econ 104(4):724-746. https:// doi.org/10.1787/536410876068

Nicoletti G, Scarpetta S (2003) Regulation, productivity and growth: OECD evidence. Econ Pol 18 (36):9-72. https://doi.org/10.1787/078677503357

OECD (2013a) Indicators of product market regulation database. http://www.oecd.org/eco/growth/ indicatorsofproductmarketregulationhomepage.htm. Accessed 8 Nov 2017

OECD (2013b) OECD economic surveys: Greece 2013. OECD Publishing, Paris. https://doi.org/ 10.1787/eco_surveys-grc-2013-en

OECD (2013c) Evaluation of competition enforcement and advocacy activities: the results of an OECD survey, DAF/COMP/WP2(2012)7/FINAL, Official OECD documents database. http:// www.oecd.org/general/official-unclassied-documents.htm. Accessed 8 Nov 2017

Voigt S (2009) The effects of competition policy on development-cross-country evidence using four new indicators. J Dev Stud 45(8):1225-1248. https://doi.org/10.1080/ 00220380902866862

Zonzilos N (2014) Assessing the macroeconomic impact of structural reforms in Greece, resource document. Foundation for Economic \& Industrial Research. https://memorandabilia.files. wordpress.com/2016/05/macro_narrative_report_en.pdf. Accessed 8 Nov 2017

Open Access This chapter is licensed under the terms of the Creative Commons Attribution 4.0 International License (http://creativecommons.org/licenses/by/4.0/), which permits use, sharing, adaptation, distribution and reproduction in any medium or format, as long as you give appropriate credit to the original author(s) and the source, provide a link to the Creative Commons license and indicate if changes were made.

The images or other third party material in this chapter are included in the chapter's Creative Commons license, unless indicated otherwise in a credit line to the material. If material is not included in the chapter's Creative Commons license and your intended use is not permitted by statutory regulation or exceeds the permitted use, you will need to obtain permission directly from the copyright holder.

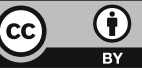

